\title{
The increasing importance of grapevine trunk diseases
}

\author{
Kovács, Cs. ${ }^{1}$ \& Sándor, E. ${ }^{2}$ \\ ${ }^{I}$ National Agricultural Research and Innovation Centre, Fruit Research Institute \\ H-4244 Ujfehértó, Vadastag 2. \\ ${ }^{2}$ University of Debrecen, Faculty of the Agricultural and Food Sciences and Environmental Management, \\ Institute of Food Science H-4032 Debrecen, Böszörményi út 138.
}

\begin{abstract}
Summary: Grapevine trunk diseases (GTDs) are destroying the woody parts of the plants, resulting decline or dieback of the grapevine. More detailed research of the GTD began in 1950s, when Hewitt et al. (1957) observed that specific symptoms cannot be detected on the diseased trunks every year. Latest results have also proved that abiotic factors affect the appearance and the severity of the disease. Moreover several pathogenic fungi may play role as causative agents (Bertsch et al., 2013). Eutypa, Botryosphaeria, Phomopsis dieback, esca disease complex, and Petri disease are considered the major GTDs, where a variety of pathogens attack the woody perennial organs of the vine and ultimately lead to the death of the plant (Lehoczky, 1974; Larignon \& Dubos, 1997; Rolshausen et al. 2010; Kotze et al., 2011; Bertsch et al., 2013; Fontaine et al., 2015).

The GTD incidence has been reported to be increased during the last decades (Úrbez-Torres et al., 2014). The esca incidence has reached $60 \%$ to $80 \%$ in some old vineyards in southern Italy (Pollastro et al., 2000; Surico et al., 2000; Calzarano \& Di Marco, 2007). The disease incidence of the esca was reported to be increased from 1.83\% to almost 13\%, between 2003 and 2007 in Hungary (Dula, 2011). There was detected a five times increase in the GTD disease incidence in the Tokaj Wine Region, Hungary between 2014 and 2016 (Bihari et al, 2016).
\end{abstract}

Keywords: grapevine trunk disease, Eutypa, Botryosphaeria and-Phomopsis dieback, esca disease complex, Petri disease, black dead arm, black foot, grapevine

\section{Iroduction}

The Grapevine Trunk Diseases (GTD) are one of the most serious disease worldwide for the grapevine (Vitis vinifera L.), which are causing considerable yield loss and economic losses in the wine industry (Rego et al., 2000; Bertsch et al., 2009; Abreo et al, 2011; Diaz et al., 2012; Kaliternam \& Milicevic, 2013; Mondello et al, 2013; Ammad et al., 2014). More and more researchers mention the appearance of the diseases severity similar to the phylloxera in Europe. The GTD has been described first in California in 1895. Ravaz identified the disease in France in 1898, as "folletage". The diseases were associated with the presence of the Stereum hirsutum (Willd.) Pers. (1800) (first described name: Thelephora hirsuta Willd. (1787) and the Phellinus igniarius (L.) Quél. (1886) (first described name: Boletus igniarius (L.) (1753) (syn.: Fomes igniarius (L.) Fr. (1849)) (Chiarappa, 2000). Intensive research of the GTD began from 1950s. Hewitt et al. (1957) observed that specific symptoms cannot be detected on the diseased trunks every year. Chiarappa et al. (1959) identified Cephalosporium and Phellinus igniarius (L.) Quél. (1886) (first described name: Boletus igniarius (L.) (1753), (syn.: Fomitiporia mediterranea M. Fischer (Fischer, 2002) species as potential pathogens from the symptomatic plants. The research of the esca complex was continued by Larignon \& Dubos (1987). Their studies focused on the question, whether the asexually reproducing (mitospore) fungi participate alone or together with basidiomycota in the evolving of the disease. The drastic increase of the disease was observed in 1990s in those countries, where the previously effectively used arsenite was banned (Mugnai et al., 1999). During this period the sodium-arsenite has been used in a limited extent in France, Portugal and in Spain, but the esca continues to spread in the winegrowing regions (Mugnai et al., 1999). Although the appearance and the type of GTD are different in the different wine region, the increase of the disease became robust at the beginning of 2000s (Chiarappa, 2000; Grosman, 2005; Graniti, 2006).

GTDs are caused by many different Ascomycete fungi, including Diatrypaceaous and Botryosphaeriaceous species, Phomopsis species, Phaeomoniella and Phaeoacremonium species, as well as Basidiomycetous fungi such as Fomitiporia mediterranea (Kuntzmann et al., 2010; Kotze et al., 2011; Bertsch et al., 2013; Úrbez-Torres et al., 2014). GTD incidence may vary between closely located vineyards possibly due to microclimate, soil composition or water supply, suggesting abiotic environmental factors are likely to have a role in the evolve of the disease. The grape variety and the type of rootstock can also affect the appearance and severity of disease symptoms (Sosnowski et al., 2007; Van Niekerk et al., 2011).

Esca disease complex, Petri disease, Eutypa, Botryosphaeria, Phomopsis dieback, black dead arm (BDA) and the 
black foot disease are considered the major GTDs worldwide, and the causal pathogens attack the woody perennial organs of the vine and ultimately lead to the death of the plant (Lehoczky, 1974; Fontaine et al., 2015).

According to Larignon et al. (2000) the esca complex was more widespread disease comparing to Eutypa dieback in France in 90's. Black dead arm was new disease in some French wine regions, including Champagne in 2000 (Larignon \& Dubos, 2001b). The importance of esca and the BDA have been realized already in the majority of French wine region in 2003 (Fotre-Muller, 2006).

The effective control of GTD faces several problems. Although the susceptibility of the different cultivars are different (Murolo \& Romanazzi, 2014) and the rootstock may also affect the frequency of the symptoms there is no grapevine cultivar known to be resistant to GTD. The protection restricts currently mainly to the prevention (healthy propagating material, prevention of pruning wounds infection).

We are summarizing the present knowledge about the different disease types of GTDs. Esca disease complex, Petri disease, Eutypa- Phomopsis- and Botryosphaeria dieback, Black Dead Arm (BDA), black foot are considered the major GTDs, are caused by a variety of pathogens which attack the woody perennial organs of the vine and ultimately lead to the death of the plant (Lehoczky, 1974; Mugnai et al., 1999; Rolshausen et al. 2005; Phillips et al., 2005; Halleen et al., 2006; Úrbez-Torres et al., 2006a; Úrbez-Torres et al., 2009; Varga, 2009; Kotze et al., 2011; Úrbez-Torres, 2011a; Hofstetter et al., 2012; Bertsch et al., 2013; Fontaine et al., 2015).

\section{Esca disease complex}

Esca is a worldwide spreading disease. The disease was already described in the ancient Greek and Latin cultures, then in the middle ages (Mugnai et al., 1999). The research of the disease began at the end of nineteenth century with Ravaz's (1898) and Viala's (1926) work. The major pathogens, which are participating in the disease: Phaeoacremonium aleophilum (Crous et al., 1996), (syn.: Calosphaeria minima Tul. \& C. Tul., (1863), Togninia minima Tul. \& C. Tul. Berl., (1900), Erostella minima Tul. \& C. Tul. (1906), Pleurostoma minimum Tul. \& C. Tul. M.E. Barr, J.D. Rogers \& Y.M. Ju (1993), Longoa paniculata Curzi (1927), a Phaeomoniella chlamydospora Crous \& W. Gams (2000) (first described name: Phaeoacremonium clamydosporum), a Phaeoacremonium sp. W. Gams, Crous, M.J. Wingf. \& Mugnai (Scheck et al., 1998c; Mugnai et al., 1999; Dupont et al., 2000). Basydiomycetes species also participate in the evolving of the esca. The most widespread fungi is Fomitiporia mediterranea (syn: Phellinus punctatus and Fomitiporia punctata M. Fischer (2002) (first described name: Poria punctata P. Karst. (1882). This species cause white rot (Mugnai et al., 1999; Fischer, 2006; Kuntzmann et al., 2010, Mikulás, 2014). Essakhi et al. (2008) identified a new Phaeoacremonium species from the Tokaj Wine Region, which described as Phaeoacremonium hungaricum. Beside the Phaeoacremonium and Phaeomoniella species can participate the Botryosphaeria obtusa Schwein (Shoemaker, 1964; Lehoczky, 1974; Cristinzio, 1978) (anamorph: Diplodia seriata de Not.) and other Botryosphaeria species (Bertsch et al., 2013), as well as Cylindrocarpon (Ilyonectria), Campilocarpon spp. (Halleen, 2006), the Stereum hirsutum (Ubrizsy, 1965; Mugnai et al., 1999; Armengol, 2001; Fischer \& Kassemeyer, 2003; Surico et al., 2006) and Phellinus igniarius (Ubrizsy, 1965).

This species can cause different necrosis in the grapevine: central necrosis, punctual, sectoral necrosis or soft rot 'Amadou' (Maher et al., 2012). The esca pathogens are able to infect the plantations at different ages. The progression of the disease may take several years, and firstly appears on the woody areas, and then the destruction of the vegetative parts can be observed (Lima et al., 2010; Bertsch et al., 2013).

Different disease appearance have been described. The Petri disease is evolving in the younger plantation, the esca is forming in the older plantations (Mostert et al., 2006; Aroca et al., 2008). The apoplexy (Figure 1.) and the chronic form 'black measles' are described in the older plantation. The apoplexy appears in the middle of summer, with suddenly wilt, falling the leaves and wrinkling the berries (Mugnai et al., 1999; Fleurat-Lessard et al., 2010; Letousey et al., 2010; Mikulás, 2014). The leaves are first light green, than change to grey-green colour.

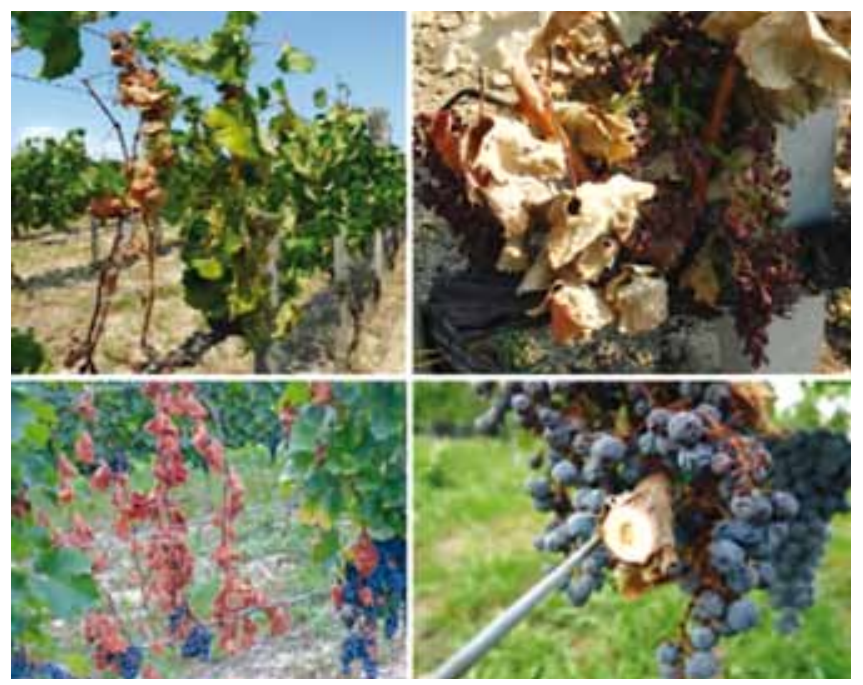

Figure 1: Apoplexy symptoms on Hárslevelü variety in Tokaj Wine Region (top) and on Merlot variety in Szekszárd Wine Region (under) Photo: Kovács and Sándor, 2015

The chronic form is usually evolving long period after the infection, typically in the 8 and 10 years old plantations (Mugnai et al., 1999; Fischer \& Kassemeyer, 2003; Mikulás, 2008; Fleurat-Lessard et al., 2010; Letousey et al., 2010; Bertsch et al., 2013; Mikulás, 2014). According to Fussler et al. (2008), the esca attacks mainly the 15 and 25 years old plantations. The most frequent internal symptoms are the sponginess and the softness of woody tissues (Figure 2.). The necrosis can spread from up to down until the place of the grafting, but they did not attack the roots (Mugnai et al., 1999). 


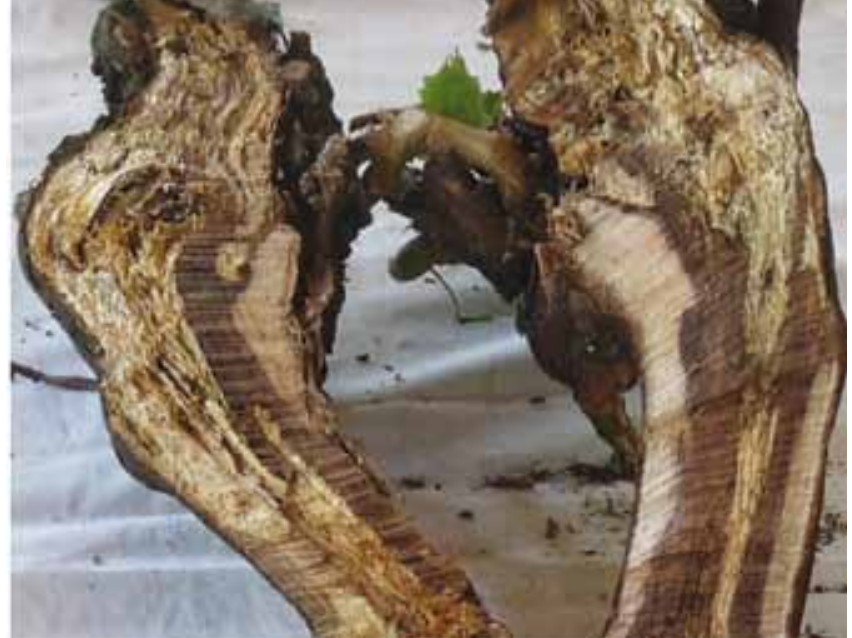

Figure 2: White rot in Chardonnay trunk Photo: Kovács, 2016

Chlorotic and necrotic lesions are visible on the leaves, which are called 'tiger stripe' (Figure 3.). These symptoms usually appear a few years after the infection, when the pathogen has colonized the vine stock, and are visible in the middle of the summer, when the dry and hot weather conditions are followed by rainy and wet one (Surico et al., 2006).

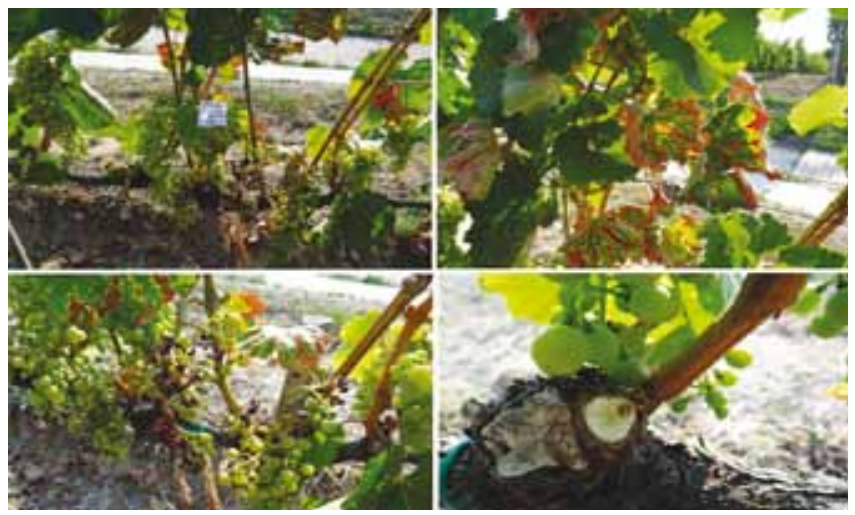

Figure 3: Esca symptoms on Furmint variety in Tokaj Wine Region Photo: Kovács and Balling, 2014

The sprouts and the twigs show decreased growth the in sprig, which they become woody in autumn. The clusters withered, the berries have low sugar content, lose their firmness, did not ripen. The disease may present just in case of some berries on the clusters (Mugnai et al., 1999).

The close relationship between the esca and the Petri disease has been reported worldwide (Ridgway et al., 2002; Halleen et al., 2003; Edwards \& Pascoe, 2004). The disease was described first by Petri (1912) at the beginning of twentieth century in South-Italy, Sicily. The typical symptoms appear in one year old shoots (Bertsch et al., 2013; Dula, 2012; Gramaje \& Armengol, 2011). The spreading of the disease is mainly through infected grafts and it cause rapid reduction in the yield (Mugnai et al., 1999). Castillo-Pando et al. (2001) and Phillips (2002) confirmed, that Botryosphaeria lutea participate in the evolving of the symptoms. The foliar symptoms are between June and September in the vegetation period. The visible symptoms are not detected in all trunks and in each year (Petit et al., 2006). The presence of the brown stripes is visible in case of rudimentary esca symptom, and it can be found mainly in the older plantations (Mugnai et al., 1999; Surico et al., 2006; Bertsch et al., 2013). The young esca is the most destructive disease in case of the new plantations (Larignon \& Dubos, 1997; Mugnai et al., 1999; Halleen et al., 2003; Martin \& Cobos, 2007). Phaeoacremonium species cause brown stripes on the trunks, while Fomitipora mediterranea causes the white rot (Mugnai et al., 1999; Mikulás, 2014). The presence of the Petri disease was detected on Merlot variety in Eger Wine Region, Hungary since 1997, resulting the necessity of replantation for 30-50\% in the vineyards (Dula, 2003, 2004). Esca was detected $11.6 \%$ in a high cordon cultivated 18 years Red Traminer variety in wine region of southern part of Balaton with Lehoczky \& Makó (1983). Later Aponyi et al. (1999) investigated the esca infection in nine wine regions between 1997 and 1998, where the infection was between 8 and $21 \%$. Rábai et al. (2008) examined the appearance of the disease between 2003 and 2005 in 13 wine regions, the highest esca presence (38.10\%) was in Pannon Wine Region Balatonboglár area. The lowest infection was in Tokaj Wine Region $(<2 \%)$ in this period. The abiotic and biotic factors affect the appearance of the disease (Maher et al., 2012).

\section{Eutypa dieback}

Eutypa dieback has been described as the most common diseases, caused by Eutypa lata (Pers.: Fr.) Tul. \& C. Tul. (syn.: E. armeniacae Hansf. \& M.V. Carter; anamorph: Libertella blepharis Tul. \& C. Tul (1863) A.L. Smith, Rappaz (1984) (Carter, 1988; 1991; Dula, 2012). Trouillas et al. (2011) described that other species (Eutypella microtheca, Eutypella citricola, Diatrypella vulgaris) can participate in the development of the disease in Australia. The pathogen can be found beyond Europe in other countries: Australia, Brazil (Paradela et al., 1993), Canada, Israel, Mexico, New-Zealand, South-Africa, USA (California, Oregon, Washington, Michigan, New York) (Carter, 1991; Munkvold, 2001). Eutypa lata infects trough the pruning wounds (English \& Davis, 1978; Lehoczky \& Moller, 1979). The disease is mainly in more than one year old, typically 4 and 5 years old plantation. The most intensive infection is in the autumn period (Ramos et al., 1975b). Black stroma of the fungus is forming in the woody tissues without bark. Disease can be expected in areas where the annual precipitation is more than $250 \mathrm{~mm}$ (Bertsch et al., 2013), according Vajna (1983) 350 $\mathrm{mm}$. The ascospores are released from the perithecia and infect the pruning wounds (English \& Davis, 1978; Moller \& Kasimatis; 1978; Gubler et al., 2005). Lehoczky \& Moller (1979) showed in their research that the annual distribution of the precipitation correlated with the disease appearance in the Hungarian vineyards in 1970s. The ascospores spread with wind in rainy weather (Lehoczky \& Moller, 1979; Gubler 
et al., 2005). The optimum temperature for the germination of the ascospores is between 22 and $25^{\circ} \mathrm{C}$, but according to Gubler et al. (2005) the pathogen can infect above $1^{\circ} \mathrm{C}$. The largest amount of spores can be detected during winter time (Ramos et al., 1975b; Petzholdt et al., 1982; Gubler et al., 2005). The typical symptoms of the disease are the wedge shaped, zonal brownish longitudinal necrotic death in the cordon, the stunted shoots and chlorotic points on the leaves (Figure 4.) (Lehoczky, 1974; Bolay et al., 1977; Moller \& Kasimatis, 1981; Duthie et al., 1991; Creaser \& Wicks, 2001; 2004; Gubler et al., 2005; Rábai et al., 2005; Hluchy, 2007; Sosnowski et al., 2009; 2011). According to Gubler et al. (2005), the stromata, producing the perithecia are in the older plantations. The perithecia was observed in some Californian vineyards on the dead plants in 1937 (Lehoczky \& Moller, 1979). Later, the stunted shoot resulted fruitless, small clusters (Lehoczky \& Moller, 1979).

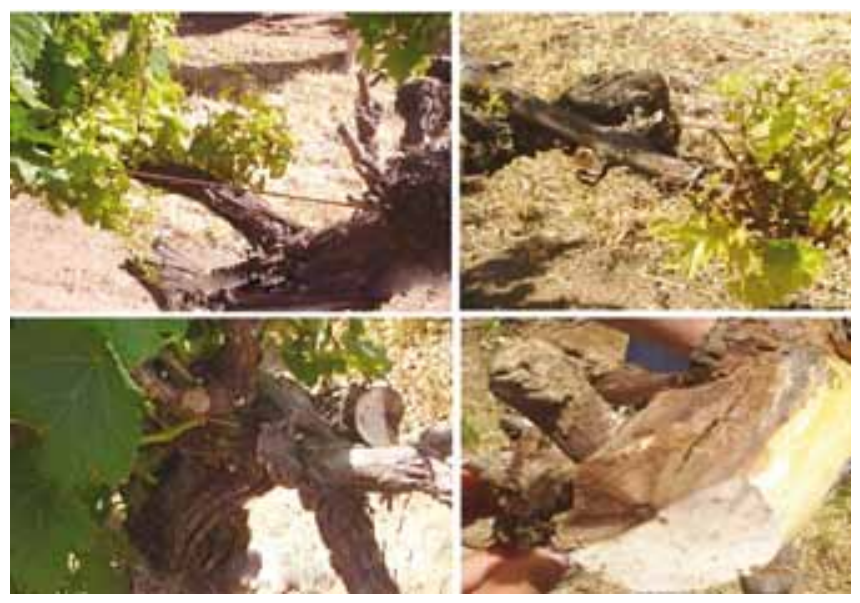

Figure 4: Eutypa dieback

Photo: Kovács, 2014, South-Australia, Barossa-Valley Wine Region

The foliar symptoms was detected in spring, on 3 and 8 years old plantations (Carter, 1988; Tey-Rulh et al., 1991). The water supply of the plant collapse due to the destruction of the pathogen. The produced metabolites obstruct the nutrient delivery in the vascular tissues (Mahoney et al. 2005).

\section{Botryosphaeria dieback}

The Botryoshaeria dieback has been described as several name: „Bot”, Black Dead Arm (BDA) excoryose, Botryosphaeria dieback, Diplodia dieback, Grapevine decline syndrome, Diplodia cane dieback, bunch rot, Botryosphaeria cancer (Phillips, 1998; Van Niekerk et al., 2003; Savocchia et al, 2007; Úrbez-Torres, 2011a; Van Niekerk et al., 2006). Several pathogens cause the necrosis (Auger et al., 2004; Van Niekerk et al., 2004). The species is latent pathogen. More than 20 several Botryosphaeria species were identified worldwide (Úrbez-Torres, 2001a), of which Diplodia mutila (Fr.) Mont. (1834) (teleomorph: Botryosphaeria stevensii Shoemaker (1964)), Diplodia seriata de Not. (1842) (teleomorph: Botryosphaeria obtusa Schwein Shoemaker
(1964) (Lehoczky, 1974; Cristinzio, 1978,), Neofusicoccum parvum Pennycook \& Samuels (1985) (teleomorph: Botryosphaeria parva (Crous et al. 2006)) are the most widespread (Bertsch et al., 2013) worldwide, and D. seriata in the Tokaj Wine Region, Hungary (Kovács et al. 2014).

The characteristics (shape, size, surface of the conidia) of anamorph form take into consideration for the taxonomical identification (Jacobs \& Rehner, 1998; Denman et al., 2000; Phillips, 2002), because the teleomorph form found rarely in nature (Shoemaker, 1964). According Alves et al. (2005) the identification based on the anamorph form is not enough for the correct identification. The species are parasites, endophytes or saprophytes (Barr, 1987; Denman et al., 2000; Phillips, 2002). Phillips (1998) has shown that the Botrysphaeria dothidea responsible for the whitish crust formation and the destruction of the buds and the shoots. The disease symptoms will be diverse and cannot detected on all infected trunks (Gubler et al., 2005; Sosnowski \& Loschiavo, 2010). First necrosis and spotting is visible on the leaves, then the leaves begin to dry (Figures 5/a, 5/b). The spout growth decrease. Cross or longitudinal dark brown discoloration present in the vascular tissue (Figure 5/c) (Larignon, 2004). This symptom is caused by B. obtusa (Castillo-Pando et al. (2001) and Larignon et al. (2001a; c). The necrosis can be observed in case of infected plants at the bud burst time. The bark turns white, where the pycnidia of the Botryosphaeria species appear in dark spots (Gubler et al., 2005), then the clusters begin to rot (Figures 6/d, 6/e) (Gubler et al., 2005; Bonfiglioli \& McGregor, 2006; Van Niekerk et al. 2006; Wunderlich et al. 2009; Mundy \& Manning, 2010).

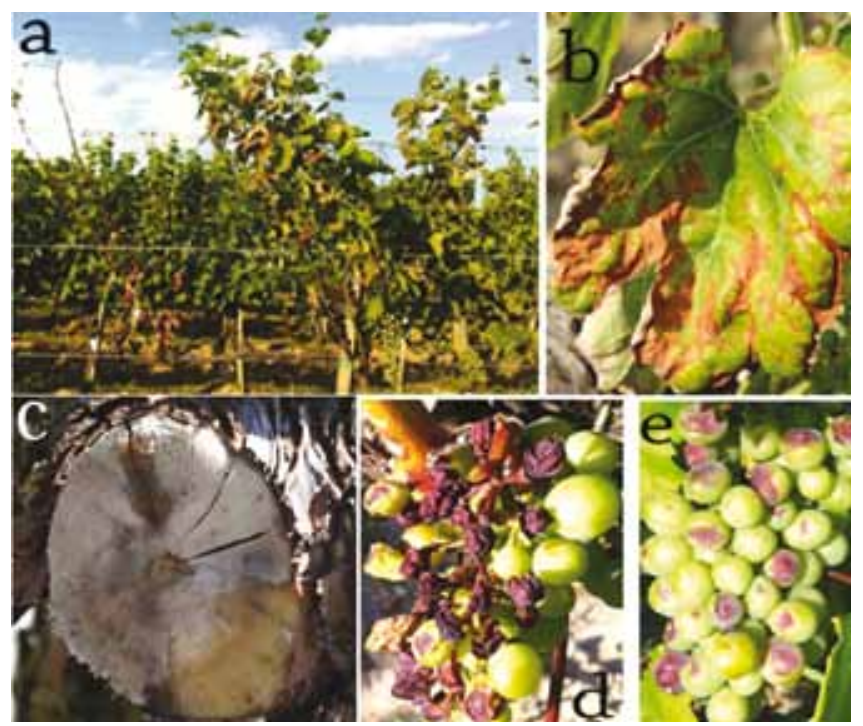

Figure 5: Botryosphaeria dieback in Furmint variety in Tokaj Wine Region Photo: Kovács, Hongtao, 2013

(a, b: necrosis on the leaves, c: necrosis on the woody tissues, d, e: rotting berries on the cluster)

The Black Dead Arm (BDA) described first by Lehoczky in 1974 in Hungary, then Cristinzio (1978), Rovesti \& Montermini (1987) identified it in Italy. The disease was identified in France in 1999 (Larignon et al., 2001c). The $D$. 
mutila was described as BDA's pathogen earlier, but some researchers also confirmed the appearance other pathogens (D. seriata, B. dothidea, L. theobromae) (Larignon et al., 2001c; Van Niekerk et al., 2006). The presence of Botryosphaeria species is mainly in the rainy period after the pruning (Lehoczky, 1974; 1988; Alfonzo et al., 2009). Diplodia mutila overwinters on the grapevine, generates pycnidia, and the rainy period favours for the release of the spores (Lehoczky, 1974).

\section{Black foot disease}

The disease may be present in the nursery or in the plantation (Halleen et al., 2006). Primary pathogens are Ilyonectria destructans (Zinssm.) Rossman, L. Lombard \& Crous (2015) (syn.: Cylindrocarpon destructans (Zinssm.) Sholten (1964); Ramularia destructans (Zinssm.) (1918), Cylindrocarpon macrodidymum Schroers, Halleen \& Crous (Halleen et al., 2004c) (syn.: Cylindrocarpon macrodidymum Schroers, Halleen \& Crous (2004); Ilyonectria macrodidyma Halleen, Schroers \& Crous (2011); Neonectria macrodidyma Halleen, Schroers \& Crous (2004). Furthermore other two species were identified: Campylocarpon fasciculare Halleen, Schroers \& Crous (2004) and Campylocarpon pseudofasciculare Halleen, Schroers \& Crous (2004) (Halleen et al., 2004c). The disease was described in France in 1961 (Maluta \& Larignon, 1991), then in Tasmania (Sweetingham, 1983), Sicily (Grasso, 1984), Portugal (Rego, 1994; Rego et al., 2000; 2001) were also found. Gugino \& Travis (2003) identified the disease in the USA, Pennsylvania. Cylindocarpon obtusisporum Cooke \& Harkn., Wollenw. (1916) (currently name: Neonectria obtusispora Cooke \& Harkn., Rossman, L. Lombard \& Crous (2014) (syn.: Fusarium obtusisporum Cooke \& Harkn. (1884)); Ramularia obtusispora Cooke \& Harkn., Wollenw. (1916) was identified in Sicily (Grasso \& Magnano di San Lio, 1975) and in California (Scheck et al., 1998a). Several Cylindrocarpon sp. was identified from the young, necrosis, basal rot and root necrosis showing trunks in Chile (Auger et al., 1999), Greece (Rumbos \& Rumbou, 2001), Spain (Armengol et al., 2001), South-Africa (Fourie et al., 2000; Fourie \& Halleen, 2001) and Australia (Edwards \& Pascoe, 2004).

The symptoms are in the growing season. The new sprouts had decreased growth activity (Picture 6/a), so the plant will die by middle-summer (Halleen et al., 2006). The plants have short internodes, small leaves, on which chlorosis, necrosis, bud lack and root lesion were in the vegetation period (Halleen et al., 2006).

Black discoloration was in the woody tissue (Scheck et al., 1998c; Halleen et al., 2006), and brown, dark strips in case of the rootstocks (Rego et al., 2000). The longitudinal vascular streaking caused by Cylindrocarpon species in the young plants (Halleen et al., 2006).

C. destructans pathogen is basal part of the rootstocks in the older plantation (Rego et al., 2000). This symptom was found in 2 and 5 years old plantation in California (Scheck et al., 1998). Typical symptoms are the striation of the venation of leaves in the nursery (Grasso \& Magnano di San Lio, 1975).

\section{Phomopsis dieback}

The Phomopsis dieback was described first by Lehoczky in a plantation in southern Hungary (Villány Wine Region). The disease is mainly in British Columbian Wine Region (Úrbez-Torres at al., 2009). The disease was caused by Diaporthe perjuncta Niessl. (1846) (Rawnsley et al., 2004) and Phomopsis viticola Sacc. (1905), (syn.: Diaporthe neoviticola Udayanga, Crous \& K.D. Hyde (2012)), Diaporthe ampelina Berk. \& M.A. Curtis R.R. Gomes, Glienke \& Crous (2013) (Gomes et al., 2013; Dissanayake et al., 2015). These species are cosmopolitan, they cause the root-and fruit rot and the necrosis of the woody tissue (Uecker, 1988).

The presence of Phomopsis viticola was reported at the beginning of 1920s and the middle of 1960s almost in all grapevine producing region: in the eastern part of the USA, Canada (Coleman, 1928; Anderson et al., 1943; Braun, 1961; Barnes, 1963; Chamberlain et al., 1964, Willison et al., 1965), California (Hewitt, 1935), Japan (Hiura, 1924) and South-Africa (Du Plessis, 1938) areas. Diaporthe perjuncta causes the stunted sprouts and symptoms on the leaves and other spouts (Rawnsley et al., 2004). Phomopsis velata (Sacc.) Traverso, 1906 syn.: Diaporthe ambigua Nitschke (1870), Diaporthe eres Nitschke (1870) and D. neotheicola A.J.L. Phillips \& J.M. Santos (2009) species were identified from the symptomatic woody tissue in California (ÚrbezTorres et al., 2013). Diaporthe eres was isolated from GTD symptomatic plants in the Tokaj Wine Region (Kovács et al., 2014).

The pycnidia are on the dead crust, under the crust and on the woody tissue. The ripened grapes cane turns white, with pycnidia on its surface (Varga, 2009; Úrbez-Torres et al., 2013). The wedge-shaped brown discoloration is on the woody tissue. The diseased plant shows decreased sprout growth and it is observed dark, blackened, irregular shape (Úrbez-Torres et al., 2013) brownish discoloration on the sprouts and leaf stalk, which become longitudinal, drying cracks (Úrbez-Torres et al., 2013). The mycelia is in the green sprouts mainly in the parenchyma tissue of the crust. Greenish-yellow, rounded, irregular chlorotic sports are on the leaves (Reddick, 1909; Úrbez-Torres et al., 2013). The symptom of the berries is in harvest period (Anco, 2011).

\section{Discussion}

The GTD incidence has been reported to be increased during the last decades worldwide (Úrbez-Torres et al., 2014; Pollastro et al., 2000; Surico et al., 2000; Calzarano \& Di Marco, 2007), and Hungary (Dula, 2011; Bihari et al, 2016). GTD incidence may vary between closely located vineyards possibly due to microclimate, soil composition 
or water supply. This suggests that not only biotic, but also abiotic environmental factors are likely having role in the development of the disease (Bertsch et al., 2013).

The GTDs are caused by different Ascomyceteous pathogens, like Diplodia seriata, different Phomopsis species, Phaeomoniella and Phaeoacremonium species, moreover Basidiomycetous fungi (e.g. Fomitiporia mediterranea) (Kuntzmann et al., 2010; Kotze et al., 2011; Bertsch et al., 2013; Úrbez-Torres et al., 2014). Different forms of GTDs have been detected in Hungary. Lehoczky (1974) described the black dead arm disease of grapevine, which is caused by Diplodia mutila (R. A. Schoemaker), in the Tokaj Wine Region. D. seriata, Diaporthe eres and D. mutila were identified from GTD symptomatic grapevines in the Tokaj Wine Region, Hungary (Kovács et al. 2014). Phaeoacremonium hungarium (S. Essakhi, L. Mugnai, G. Surico \& P. W. Crous (Pers.)) has been identified as new Phaeoacremonium species in the Tokaj Wine Region (Essakhi et al., 2008). A new GTD pathogen, Seimatosporium vitis was recently described in Hungary (Váczy, 2016).

\section{Acknowledgement}

This work was supported by the publication is supported by the TÁMOP 4.2.4.A/2-11-1-2012-0001 project (Nemzeti Kiválóság Program Hazai hallgatói, illetve kutatói személyi támogatást biztosító rendszer kidolgozása és müködtetése konvergencia program). The project is co-financed by the European Union and the European Social Fund. E. Sándor was supported by the ,Research Grant of the University of Debrecen. The research was supported by cost action fa1303. supported through the new national excellence program of the ministry of human capacities.

\section{References}

Abreo, E., Martinez, S., Bettuci, L. \& Lupo, S. (2011): Phaeomoniella chlamydospora and Phaeoacremonium spp. in grapevines from Uruguay. Phytopathologia Mediterranea. 50: 7785.

Alfonzo, A., Conigliaro, G., Torta, L., Burruano, S. \& Monschetti, G. (2009): Antagonism of Bacillus subtilis strain AG1 against vine wood fungal pathogens. Phytopathologia Mediterranea. 48: 155-158.

Alves, A., Phillips, A. J. L., Henriques, I. \& Correia, A. (2005): Evaluation of amplified ribosomal DNA restriction analysis as a method for the identification of Botryosphaeria species. FEMS Microbiology Letters. 245: 221-229.

Ammad, F., Benchare, M. \& Toumi, M. (2014): Fungal pathogens associated with grapevine wood lesions in Algeria. International Journal of Agronomy and Agricultural Research. 4: 8-15.

Anco, D. J., Erincik, O. \& Ellis M. A. (2011): Phomopsis Cane and Leaf Spot of Grape. Ohio State University Extension. Fact Sheet: HYG-3031-11.

Anderson, H. W. \& Colby, A. S. (1943): Dead arm disease of grape in Illinois. Plant Disease Report. 27: 245-246.
Aponyi I., Rábai A. \& Mikulás J. (1999): Early dieback of grapevine stocks in Hungary. $1^{\text {st }}$ International Workshop on Grapevine Trunk Diseases, abstract. 19.

Armengol, J., Vicent, A., Torné, L., García-Figueres, F. \& García-Jiménez, J. (2001): Fungi associated with esca and grapevine decline in Spain: a three-year survey. Phytopathologia Mediterranea. 40: 325-329.

Aroca, A., Raposo, R. \& Lunello, P. (2008): A biomarker for the identification of four Phaeoacremonium species using the b-tubulin gene as a target sequence. Applied Microbiology and Biotechnology. 80: 1131-1140.

Auger J., Droguett, A. \& Esterio, M. (1999): The Red Globe decline. [In: Proceedings of the $1^{\text {st }}$ International Workshop on Grapevine Trunk Diseases: Esca and grapevine declines.] 1999. Október 1-3., Siena, Olaszország.

Auger, J., Esterio, M., Ricke, G. \& Terez I. (2004): Black dead arm and basal canker of Vitis vinifera cv. Red Globe caused by Botryosphaeria obtusa in Chile. Plant Disease. 88: 1286.

Barnes, E. H. (1963): Incidence of systemic dead-arm and its relation to topography in Michigan vineyards. Plant Disease Report. 47: 872-874

Barr, M. E. (1987): Prodromus to Class Loculoascomycetes. Amherst, Massachusetts. 186.

Bertsch, C., Larignon, P., Farine, S., Clement, C. \& Fontaine, F. (2009): The spread of grapevine trunk disease. Science. 8: 721.

Bertsch, C., Ramírez-Suero, M., Magnin-Robert, M., Larignon, P., Chong, J., Abou-Mansour, E., Spagnolo, A., Clément, C. \& Fontaine, F. (2012): Grapevine trunk diseases: complex and still poorly understood. Plant Pathology. 62: (2), 243-265.

Bihari Z., Éles S., Balling P. \& Pableczki B. (2016): A Tokaji Borvidék szőlöültetvényeinek egészségi állapotváltozása az elmúlt három évben. Szőlő-levél. 9: 5-9.

Bolay, A. \& Moller, W. J. (1977): Eutypa armeniacae Hansf. \& Carter, agent d'un grave dépérissement de vignes en production. Revue suisse de Viticulture Arboriculture, Horticulture. 9: 241-251.

Bonfiglioli, R. \& McGregor, S. (2006): The Botryosphaeria conundrum - a New Zealand perspective. The Australian \& New Zealand Grapegrower \& Winemaker. 512: 49-53.

Braun, A. J. (1961): Dead-arm, a disease of grapes. Farm Research. 27: 7.

Calzarano, F. \& Di Marco, S. (2007): Wood discoloration and decay in grapevines with esca proper and their relationship with foliar symptoms. Phytopathologia Mediterranea. 46: 96-101.

Carter, M. V. (1988): Eutypa dieback [In: Pearson, R. C. Goheen, A. C. (szerk.) Compendium of Grape Diseases.] American Phytopathological Society, Press, St. Paul, USA. 32-34.

Carter, M. V. (1991): The status of Eutypa lata as a pathogen. International Mycologycal Institute, Phytopathological Paper. 32.

Castillo-Pando, M., Somers, A., Green, C. D., Priest, M. \& Sriskanthades, M. (2001): Fungi associated with dieback of Semillon grapevines in the Hunter Valley of New South Wales. Australasian Plant Pathology. 30: 59-63.

Chamberlain, G. C., Willison, R. S., Townshend, J. L. \& de Ronde, J. H. (1964): Two fungi associated with the dead-arm disease of grape. Canadian Journal of Botany. 42: 351-355.

Chiarappa, L. (1959): Wood decay of grapevine and its relationship with black measles disease Phytopathology. 49: 510-519. 
Chiarappa, L. (2000): Esca (black measles) of grapevine. An overview. Phytopathologia Mediterranea. 39: 11-15.

Coleman, L. C. (1928): The dead-arm disease of grapes in Ontario. A preliminary study. Scientific Agriculture. 8: 281-315.

Creaser, M. L. \& Wicks, T. J. (2001): Yearly variation in Eutypa dieback symptoms and the relationship to grapevine yield. The Australian and New Zealand Grapegrower and Winemaker. 452: 50-52.

Creaser, M. L. \& Wicks, T. J. (2004): Short-term effects of remedial surgery to restore productivity to Eutypa lata infected vines. Phytopathologia Mediterranea. 43: (1), 105-107.

Cristinzio G. (1978): Gravi attacchi di Botryosphaeria obtusa su vite in provincia di Isernia. Informatore fitopatologico. 28: 21-23.

Denman, S., Crous, P. W., Taylor, J. E., Kang, J. C., Pascoe, I. \& Wingfield, M. J. (2000): An overview of the taxonomic history of Botryosphaeria, and a re-evaluation of its anamorphs based on morphology and ITS rDNA phylogeny. [In: Seifert, K. A. - Gams, W. - Crous, P. W. - Samuels, G. J. (szerk.) Molecules, morphology and classification: Towards monophyletic genera in the Ascomycetes.] CBS Press, Koppenhága, Hollandia, Studies in Mycology. 45: 129-140.

Diaz, G. A., Elfar, K. \& Latorre, B. A. (2012): First report of Seimotosporium botan associated with trunk disease of grapevine (Vitis vinifera) in Chile. Plant Disease. 96: 1696-1696.

Dissanayake, A. J., Liu, M., Zhang W., Chen, Z., Udayanga D., Chukeatirote, E., Li, X., Yan J. \& Hyde, K. D. (2013): Morphological and molecular characterisation of Diaporthe species associated with grapevine trunk disease in China. Persoonia. 31: 1-41.

Du Plessis, S. J. (1938): The occurrence of the dead-arm disease of vines in South Africa. Union of South Africa Department of Agriculture and Forestry Sciences Bulletin. 175: 1-9.

Dula B.(2011): Korai szőlőtőke-pusztulást okozó, szaporítóanyaggal terjedő kórokozó gombák. Növényvédelem. 47: 461-468.

Dula B. (2012): Kordonkar-elhalást és korai tőkepusztulást okozó betegségek. [In: Kürti A.- Rácz I. (szerk.) Diagnosztikai és szőlővédelmi kézikönyv GYAKORLÓ SZAKEMBEREKNEK.] Budapest. 76-87.

Dula T. (2003): Szőlőleromlás, korai tőkeelhalás (,grapevine decline"). Gyakorlati Agrofórum. 14: (5), 17-25.

Dula T. (2004): Esca és Petri betegség. Gyakorlati Agrofórum. Extra 7. 16: (5), 12-15.

Dupont, J, Wassila, L., Magnin, S., Larignon, P. \& Roquebert, M. F. (2000): Phaeoacremonium viticola, a new species associated with Esca disease of grapevine in France. Mycologia. 9:. 499-504.

Duthie, J. A., Munkvold, G. P. \& Marois, J. J. (1991): Relationship between age of vineyard and incidence of Eutypa dieback. Phytopathology. 81: 1184-1193.

Edwards, J. \& Pascoe, I. G. (2004): Occurrence of Phaeomoniella chlamydospora and Phaeoacremonium aleophilum associated with Petri disease and esca in Australian grapevines. Australasian Plant Pathology. 33: 273-279.

English, H. \& Davis, J. R. (1978): Eutypa armeniacae in apricot: pathogenesis and induction of xylem soft rot. Hilgardia. 46: 193204.

Essakhi, S., Mugnai, L., Crous, P. W., Groenewald, J. Z. \& Surico, G. (2008): Molecular and phenotypic characterisation of novel Phaeoacremonium species isolated from esca diseased grapevines. Persoonia. 21: 119-134.
Fischer, M. \& Kassemeyer, H. (2003): Review Fungi associated with Esca disease of grapevine in Germany. Vitis. 42: (3), 109-116.

Fischer, M. (2002): A new wood-decaying basidiomycete species associated with esca of grapevine: Fomitiporia mediterranea (Hymenochaetales). Mycological Progress. 1: (3), 315-324.

Fischer, M. (2006): Biodiversity and geographic distribution of basidiomycetes causing esca-associated white rot in grapevine: a worldwide perspective. Phytopathologia Mediterranea. 45: 30-42.

Fleurat-Lessard, P. Luini, E., Berjeaud, J. M. \& Roblin, G. (2010): Diagnosis of grapevine esca disease by immunological detection of Phaeomoniella chlamydospora. Australian Journal of Grape and Wine Research. 16: (3), 455-463

Fontaine, F., Pinto, C., Vallet, J., Clément, C., Gomes, A. C. \& Spagnolo, A. (2015): The effects of grapevine trunk diseases (GTDs) on vine physiology. European Journal of Plant Pathology. $1-15$

Fotre Muller, M. J. (2006): Maladies du Bois de la Vigne. Observatoire des Maladies du Bois: Bilan 2003-2005. Avertissements Agricoles Alsace.

Fourie, P. H. \& Halleen, F. (2001): Diagnosis of fungal diseases and their involvement in dieback disease of young vines. Wynboer. 149: $19-23$

Fourie, P. H., Halleen, F. \& Volkmann, A. S. (2000): Fungi associated with grape wood, root and trunk diseases: A summary of the 1999-2000 results from the diagnostic service at Nietvoorbij. [In: Proceedings of the $2^{\text {nd }}$ International Viticulture and Enology Congress (szerk.)], 2000. November 8-10., Cape Town, Dél-Afrika.

Fussler, L., Kobes, N., Bertrand, F., Maumy, M., Grosman, J. \& Savary, S. (2008): A characterization of grapevine trunk diseases in France from data generated by the national grapevine wood diseases survey. Phytopathology. 98: 571-579.

Gomes, R. R., Glienke, C., Videira, S. I. R., Lombard, L., Groenewald, J. Z. \& Crous, P. W. (2013): Diaporthe: a genus of endophytic, saprobic and plant pathogenic fungi. Persoonia. 1-41.

Gramaje, D. \& Armengol, J. (2011): Fungal Trunk Pathogens in the Grapevine Propagation Process: Potential Inoculum Sources, Detection, Identification, and Management Strategies. Plant Disease. 95: (9), 1040-1055.

Graniti, A., Surico, G. \& Mugnai, L. (2006): Esca of grapevine: a disease complex or a complex of diseases?. Phytopathologia Mediterranea. 39: 16-20.

Grasso, S. (1984): Infezioni di Fusarium oxysporum e di Cylindrocarpon destructans associate a una moria di giovani piante di vite in Sicilia. Informatore Fitopatologico. 1: 59-63.

Grosman, J. (2005): Bilan phytosanitaire de la vigne en 2005. Phytoma Défense Végét. 587: 18-23.

Gubler, W. D., Rolshausen, P. E., Trouillase, F. P., Úrbez, J. R. \& Voegel, T. (2005): Grapevine trunk diseases in California. RESEARCH UPDATE Practical Winery\&Vineyard Journal. 1-9.

Gugino, B. K. \& Travis, J. W. (2003): Suppression of Cylindrocarpon destructans utilizing composted soil amendments. Phytopathology. 93: S31.

Halleen, F., Crous, P. W. \& Petrini, O. (2003): Fungi associated with healthy grapevine cuttings in nurseries, with special reference to pathogens involved in the decline of young vines. Australasian Plant Patholology. 32: 47-52. 
Halleen, F., Fourie, P. H. \& Crous, P. W. (2006): A review of black foot disease of grapevine Phytopathologia Mediterranea. 45: S55-S67.

Hewitt, W. B. (1935): Dead-arm disease of grapes in California. Plant Disease Report. 19: 309-310.

Hewitt, W. B. (1957): Some manifestations of black measles of grapevines. Phytopathology. 47: 16. (abstract)

Hiura, M. (1924): On the Dead Arm of grapes in the vicinity of Sapporo. Sapporo Agriculture and Forestry School Bulletin. 67.

Hluchy, M., Zacharda, M., Lastuvka, Z., Bagar, M., Jetmarová, E., Vanek, G., Szőke L. \& Plísek, B. (2007): A gyümölcsfák és a szőlő betegségei és kártevői. Biocont Laboratory Ltd. 266.

Hofstetter, V., Buyck, B., Croll, D., Viret, O., Couloux, A. \& Gindro, K. (2012): What if esca disease of grapevine were not a fungal disease? Fungal Diversity. 54: 51-67.

Jacobs, K. A. \& Rehner, S. A. (1998): Comparison of cultural and morphological characters and ITS sequences in anamorphs of Botryosphaeria and related taxa. Mycologia. 90: 601-610.

Kaliternam, A. \& Milicevic, T. (2013): First report of Neofusicoccum parvum associated with grapevine trunk diseases in Croatia. Plant Disease. 97: 1656-1656.

Kotze, C., Niekerk, J. V., Mostert, L., Halleen, F. \& Fourie, P. (2011): Evaluation of biocontrol agents for grapevine pruning wound protection against trunk pathogen infection. Phytopathology Mediterranea. 50: S247-S263.

Kovács, Cs., Peles, F., Bihari Z. \& Sándor E. (2014): Endophytic fungi connected to grapevine trunk diseases, from the Tokaj Wine Region, Hungary. Növényvédelem 50: 153-159.

Kuntzmann, P., Villaume, S., Larignon, P. \& Bertsch, C. (2010): Esca, BDA and Eutypiosis: foliar symptoms, trunk lesions and fungi observed in diseased vinestocks in two vineyards in Alsace. Vitis 49: (2), 71-76.

Kuntzmann, P., Villaume, S., Larignon, P. \& Bertsch, C. (2010): Esca, BDA and eutypiosis: foliar symptoms, trunk lesions and fungi observed in diseased vinestocks in two vineyards in Alsace. Vitis. 49: 71-76.

Larignon, P. \& Dubos, B. (1987): Les séquences parasitaires impliquées dans le syndrome de l'esca. Symposium sur la lutte integrée en viticulture. Logrono. 1987. Március 3-5.

Larignon, P. \& Dubos, B. (1997): Fungi associated with esca disease in grapevine. European Journal of Plant Pathology. 103: 147-157.

Larignon, P. \& Dubos, B. (2001a): The Villainy of Black Dead Arm. Wines Vines. 82: 86-89.

Larignon, P. \& Dubos, B. (2001b): Black dead arm a new disease - not to be confused with esca. Phytoma. 538: 26-29.

Larignon, P. (2004): Réflexions sur l'esca. Phytoma - La Défense des Végétaux. 576: 28-31.

Larignon, P., Fulchic, R., Cera, L. \& Dubos, B. (2001c): Observation on black dead arm in French vineyards. Phytopathologia Mediterranea. 40: S336-S342.

Lehoczky J. \& Makó Sz (1983): The dieback caused by Stereum hirsutum in grapevine. Kertgazdaság. 15: 53-66.

Lehoczky J. \& Moller, W. J. (1979): Eutipás rák és tőkeelhalás, a szőlő Magyarországon most felismert súlyos betegsége. Horticultural Science. 11: (2), 37-52.
Lehoczky J. (1974): Black dead arm disease of grapevine caused by Botryosphaeria stevensii infection. Acta Phytopathologica Academie Scientiarum Hungaricae. 9: 319-327.

Lehoczky J. (1988): Black Dead Arm. [In: Pearson, R. C. Goheen, A. C. (szerk.) Compendium of Grape Diseases.] American Phytopathological Society, Press, St. Paul, USA. 35.

Letousey, P., Baillieul, F., Perrot, G., Rabenoelina, F., Boulay, M., Vaillant-Gaveau, N., Clément, C. \& Fontaine, F. (2010): Early events prior to visual symptoms in the apoplectic form of grapevine esca disease. Phytopathology. 100: (5), 424-431.

Lima, M. R. M., Mafalda, L., Felgueiras-Graçxa, G., Rodrigues, J. E. A., Barros, A., Gilana, M. \& Dias, A. C. (2010): NMR metabolomics of esca disease-affected Vitis vinifera $\mathrm{cv}$. Alvarinho leaves. Journal of Experimental Botany. 61: (14), 4033-4042.

Maher, N., Piot, J., Bastien, S., Vallance, J., Rey, P. \& GuerinDubrana, L. (2012): Wood necrosis in Esca-affected vines: types, relationships and possible links with foliar symptom expression. Journal International des Sciences de la Vigne et du Vin. 46: 15-27.

Mahoney, N., Molyneux, R. J., Smith, L. R., Schoch, T. K., Rolshausen, P. E. \& Gubler, W. D. (2005): Dying-arm disease in grapevines: Diagnosis of infection with Eutypa lata by metabolite analysis. Journal of Agricultural and Food Chemistry. 53: 81488155.

Maluta, D-R. \& Larignon, P. (1991): Pied-noir: mieux vaut prévenir. Viticulture. 11: 71-72.

Martin, M. T. \& Cobos, R. (2007): Identification of fungi associated with grapevine decline in Castilla y Leon (Spain). Phytopathologia Mediterranea. 46: 18-25.

Mikulás J. (2008): Korai tőkeelhalással (Esca) kapcsolatos feladatok szüret környékén. Agrofórum: a növényvédők és növénytermesztők havilapja. 19: (10), 42-45.

Mikulás J. (2014): A szőlőtőkék korai tőkeelhalása. Agrofórum. 8: 74-81.

Moller, M. J. \& Kasimatis, A. N. (1978): Dieback of grapevines caused by Eutypa armeniacae. Plant Disease Report. 62: 254-258.

Moller, W. J. \& Kasimatis, A. N. (1981): Further evidence that Eutypa armeniacae - not Phomopsis viticola - incites dead arm symptoms on grape. Plant Disease. 65: 429-431.

Mondello, V., Piccolo, S., Conigliaro, G., Alfonzo, A., Torta, L. \& Bunuano, S. (2013): First report of Neofusiccoccum vitifusiforme and presence of other Botryosphaeriaceae species associated with Botryosphaeria dieback of grapevine in Sicily (Italy). Phytopathologia Mediterranea. 52: 388-396.

Mostert, L., Groenewald, J. Z., Summerbell, R. C., Gams, W. \& Crous, P. W. (2006): Taxonomy and pathology of Togninia (Diaporthales) and its Phaeoacremonium anamorphs. Studies in Mycology. 54: 1-115.

Mugnai, L., Graniti, A. \& Surico, G. (1999): Esca (black measels) and brown wood-streaking: two old and elusive diseases of grapevines. Plant Disease. 83: 404-416

Mundy, D. \& Manning, M. (2010): Ecology and management of grapevine trunk diseases in New Zealand?: a review. New Zealand Plant Protection. 63: 160-166.

Munkvold, G. P. (2001): Eutypa dieback of grapevine and apricot. Online. Plant Health Progress. /doi:10.1094/PHP-2001-0219-01-DG/

Murolo, S. \& Romanazzi, G. (2014): Effect of grapevine cultivar, rootstock and clone on esca disease. Australian Plant Pathology. 43: 215-221. 
Paradela Filho, O., Ribeiro, I. J. A., Braga, F. G., Nogueira, E. M. C., Pesce, G., Kuniyuki, H., Fossa, E., Rodrigues, N. J. \& Feichtenberger, E. (1993): Eutypa lata, the agent of grape decline in Sao Paolo state. Summa Phytopathologica. 19: 86-89.

Petit, A. N., Vaillant, N, Boulay, M., Clément, C. \& Fontaine, F. (2006): Alteration of Photosynthesis in Grapevines Affected by Esca. Ecology and Epydemiology, Phytopatology. 96: (10), 10601066.

Petzoldt, C. H., Moller, W. J. \& Sall, M. A. (1982): Grapevines show seasonal differences in susceptibility to Eutypa. California Agriculture, March-April. 4-5.

Phillips, A. J. L. (1998): Botryosphaeria dothidea and other fungi associated with Excoriose and dieback of grapevines in Portugal. Journal of Phytopathology. 146: 327-332.

Phillips, A. J. L. (2002): Botryosphaeria species associated with diseases of grapevines in Portugal. Phytopathologia Mediterranea. 41: 3-18.

Phillips, A. J. L., Rumbos, I. C., Alves, A. \& Correia, A. (2005): Morphology and phylogeny of Botryosphaeria dothidea causing fruit rot of olives. Mycopathologia. 159: 433-439.

Pollastro, S., Dongiovanni, C., Abbatecola, A. \& Faretra, F. (2000): Observations on the fungi associated with esca and on spatial distribution of esca-symptomatic plants in Apulian (Italy) vineyards. Phytopathologia Mediterranea. 39: 206-210.

Rábai A., Dula T. \& Mugnai, L. (2008): Distribution of esca disease in Hungary and the pathogens causing the syndrome. Acta Phytopathologica et Entomologica Hungarica. 43: 45-54.

Rábai A., Morvai Sz., Ember I. \& Fischl G. (2005): Szőlőtőkepusztulás Veszprém megyében. Növényvédelem. 10: (41), 461-466.

Ramos, D. E., Moller, W. J. \& English, H. (1975b): Production and dispersal of ascospores of Eutypa armeniacae in California. Phytopathology. 65: 1364-1371.

Ravaz, L. (1898): Sur le folletage. Revue Viticulture. 10: 184-186.

Rawnsley, B., Wicks, T. J., Scott, E. S. \& Stummer, B. E. (2004): Diaporthe perjuncta does not cause Phomopsis cane and leaf spot disease of grapevine in Australia. Plant Disease. 88: 1005-1010.

Rego, C., Nascimento, T. \& Oliveira, H. (2001): Characterisation of Cylindrocarpon destructans isolates from grapevines in Portugal. Phytopathologia Mediterranea. 40: S343-S350.

Rego, C., Oliveira, H., Carvalho, A. \& Phillips, A. J. L. (2000): Involvement of Phaeoacremonium spp. and Cylindrocarpon destructans with grapevine decline in Portugal. Phytopathologia Mediterranea. 39: 76-79.

Rego, M. C. (1994): Nova e grave micose da videira em Portugal. Agente responsável: Cylindrocarpon destructans (Zins.) Scholten. Publicação do Laboratório de Patologia Vegetal Veríssimo de Almeida. 67: 1-4.

Ridgway, H. J., Sleight, B. E. \& Stewart, A. (2002): Molecular evidence for the presence of Phaeomoniella chlamydospora in New Zealand nurseries, and its detection in rootstock mothervines using species-specific PCR. Australasian Plant Pathology. 31: 267-271.

Rolshausen, P. E. \& Gubler, W. D. (2005): Use of boron for the control of Eutypa dieback of grapevines. Plant Disease. 89: 734-738.

Rolshausen, P. E., Úrbez-Torres, J. R., Rooney-Latham, S., Eskalen, A., Smith, R. J. \& Gubler, W. D. (2010): Evaluation of pruning wound susceptibility and protection against fungi associated with grapevine trunk diseases. American Journal of Enology and Viticulture. 61: 113-119.
Rovesti, L \& Montermini, A. (1987): Un deperimento della vite causato da Sphaeropsis malorum diffuso in provincia di Reggio Emilia. Informatore Fitopatologico. 1: 59-61.

Rumbos, I. \& Rumbou, A. (2001): Fungi associated with esca and young grapevine decline in Greece. Phytopathologia Mediterranea. 40: S330-S335.

Savocchia, S., Steel, C. C., Stodartm B. J. \& Somers, A. (2007): Pathogenicity of Botryosphaeria species from declining grapevines in sub tropical regions of Eastern Australia. Vitis. 46: 27-32.

Scheck, H. J., Vasquez, S. J. \& Gubler, W. D. (1998c): First report of three Phaeoacremonium spp. causing young grapevine decline in California. Plant Disease. 82: 590. (abstract)

Scheck, H. J., Vasquez, S. J., Gubler, W. D. (1998a): First report of black-foot disease, caused by Cylindrocarpon obtusisporum, of grapevine in California. Plant Disease. 82: 448.

Scheck, H. S., Vasquez, S. J., Fogle, D. \& Gubler, W. D. (1998b): Grape growers report losses to black-foot and grapevine decline. California Agriculture. 52: 19-23.

Shoemaker, R. A. (1964): Conidial states of some Botryosphaeria species on Vitis and Quercus. Canadian Journal of Botany. 42: 1297-1301.

Sosnowski, M. \& Loschiavo, A. (2010): Management of Eutypa dieback and Botryosphaeria canker in south-western Western Australian vineyards. SAR 06/01 Final Report to Grape and Wine Researcgramaje and Development Corporation. 2010 január.

Sosnowski, M. R., Shtienberg, D., Creaser, M. L., Wicks, T. J., Lardner, R. \& Scott, E. S. (2007): The influence of climate on foliar symptoms of Eutypa dieback in grapevines. Phytopathology. 97: 1284-1289.

Surico G., Mugnai, L. \& Marchi, G. (2006): Older and more recent observations on esca: a critical overview. Phytopathologia Mediterranea. 45: 68-86.

Surico, G., Marchi, G., Braccini, P. \& Mugnai L. (2000): Epidemiology of esca in some vineyards in Tuscany (Italy). Phytopathologia Mediterranea. 39: 190-205.

Sweetingham, M. (1983): Studies on the nature and pathogenicity of soilborne Cylindrocarpon spp. Ph.D. Thesis, University of Tasmania.

Tey-Rulh, P., Philippe, I., Renaud, J. M., Tsoupras, G., De Angelis, P., Fallot, J. \& Tabacchi, R. (1991): Eutypine, a phytotoxin produced by Eutypa lata the causal agent of dying-arm disease of grapevine. Phytochemistry. 30: 471-473.

Trouillas, F. P., Pitt, W. M., Sosnowski, M. R., Huang, R., Peduto, F., Loschiavo, A., Savocchia, S., Scott, E. S. \& Gubler, W. D. (2011): Taxonomy and DNA phylogeny of Diatrypaceae associated with Vitis vinifera and other woody plants in Australia. Fungal Diversity. 49: 203-223.

Ubrizsy G. (1965): Növénykórtan II. Akadémiai Kiadó, Budapest, Magyarország. 924.

Uecker, F. A. (1988): A world list of Phomopsis names with notes on nomenclature, morphology and biology. Mycologia memoir No.13 J. Cramer, Berlin.

Úrbez-Torres, J. R. \& Gubler, W. D. (2011b): Susceptibility of grapevine pruning wounds to infection by Lasiodiplodia theobromae and Neofusicoccum parvum. Plant Pathology. 60: 261-270.

Úrbez-Torres, J. R. (2011a): The status of Botryosphaeriaceae species infecting grapevines. Phytopathology Mediterranea. 50: $5-45$. 
Úrbez-Torres, J. R., Adams, P., Kamas, J. \& Gubler, W. D. (2009): Identification, incidence, and pathogenicity of fungal species associated with grapevine dieback in Texas. American Journal of Enology and Viticulture. 60: (4), 497-507.

Úrbez-Torres, J. R., Haag, P., Bowen, P. A. \& et O'Gorman, D. T. (2014): Grapevine Trunk Diseases in British Columbia: Incidence and characterization of the fungal pathogens associated with esca and Petri diseases of grapevine. Plant Disease. 98: (4), 469-482.

Úrbez-Torres, J. R., Leavitt, G. M., Voegel, T. M. \& Gubler, W. D. (2006a): Identification and distribution of Botryosphaeria spp. associated with grapevine cankers in California. Plant Disease. 90: (12), 1490-1503.

Úrbez-Torres, J. R., Peduto, F., Smith, R. J. \& Gubler, W. D. (2013): Phomopsis dieback: A grapevine trunk disease caused by Phomopsis viticola in California. Plant Disease. 97: 1571-1579.

Váczy K. Z. (2016): First Report of Seimatosporium vitis associated with Grapevine Trunk Disease Symptoms in Hungary. Plant Disease. 101: (1), 253.

Vajna L. (1983): Eutipás ágrákosodás. [In: Vajna L. (szerk.) A gyümölcsfák korai elhalását okozó gombás betegségek.] Budapest, Mezőgazdasági Könyvkiadó. 1-174.

Van Niekerk J. M., Crous, P. W., Fourie, P. H., Groenewald, J. Z. \& Halleen, F. (2003): Botryosphaeria canker and dieback of grapevines. Proceedings of the $8^{\text {th }}$ International congress of Plant Pathology, 2003. Február 1-2., Christchurch, Új-Zéland. 339.
Van Niekerk, J. M., Bester, W., Halleen, F., Crous, W. P. \& Fourie, H. (2011): The distribution and symptomatology of grapevine trunk disease pathogens are influenced by climate. Phytopathologia Mediterranea. 50: S98-S111.

Van Niekerk, J. M., Crous, P. W., Groenewald, J. Z., Fourie, P. H. \& Halleen, F. (2004): DNA phylogeny, morphology and pathogenicity of Botryosphaeria species on grapevines. Mycologia. 96: 781-798

Van Niekerk, J. M., Fourie, P. H., Halleen, F. \& Crous, P. W. (2006): Botryosphaeria spp. as grapevine trunk disease pathogens. Phytopathologia Mediterranea. 45: S43-S54.

Varga Z. (2009): Vitis fajok és fajták tőkepusztulásának összehasonlító vizsgálata és a védekezési lehetőségei. $\mathrm{PhD}$ dolgozat. 113.

Viala, P. (1926): Recherces sur les maladies de la vigne. Esca. Annles des Épiphyties. 12: 5-108.

Willison, R. S., Chamberlain, G. C., Townsend, J. L. \& de Ronde, J. H. (1965): Epidemiology and control of dead-arm of grapes. Canadian Journal of Botany. 43: 901-914.

Wunderlich, N., Ash, G., Steel, C., Raman, H. \& Savocchia, S. (2009): Trunk disease pathogens within the Botryosphaeriaceae are associated with bunch rot disease in the Hunter Valley. The Australian \& New Zealand Grapegrower \& Winemaker. 548: 35-38. 